НАУКОВИЙ ВІСНИК

Scientific messenger of Lviv National University of
Veterinary Medicien and Biotecthologies

(1)

in

RIIS: VETERINARY SCIENC
Науковий вісник Дьвівського національного університету ветеринарної медицини та біотехнологій імені С.3. Гжицького. Серія: Ветеринарні науки

Scientific Messenger of Lviv National University of Veterinary Medicine and Biotechnologies. Series: Veterinary sciences

UDC 638.591 .16

\title{
Clinical symptoms of damage to the lateral surface of the tibia of dairy cows of different phenotype in the conditions of industrial dairy production
}

\author{
L. Roman ${ }^{1}$, S. Sidashova ${ }^{2}$, I. Popova ${ }^{1}$, N. Stepanova ${ }^{1}$, V. Chornyi ${ }^{1}$, B. Gutyj ${ }^{3}$ \\ ${ }^{1}$ Odessa State Agrarian University, Odessa, Ukraine \\ ${ }^{2}$ Institute of Animal Breeding and Genetics nd. a. M. V. Zubets of National Academy of Agrarian Science of Ukraine, \\ Kiev, Ukraine \\ ${ }^{3}$ Stepan Gzhytskyi National University of Veterinary Medicine and Biotechnologies Lviv, Ukraine
}

Article info

Received 21.09.2020

Received in revised form 19.10.2020

Accepted 20.10.2020

Odessa State Agrarian University, Panteleymonyvska St., 13, Odessa 65012, Ukraine.

Tel : +38-098-326-20-60 E-mail: liliyaroman64@gmail.com

Institute of Animal Breeding and Genetics nd. a. M. V. Zubets of National Academy of Agrarian Science of Ukraine

Pohrebnyaka Str., 1, Chubynske, Boryspil region, Kyiv district 08321, Ukraine.

Stepan Gzhytskyi National University of Veterinary Medicine and Biotechnologies Lviv, Pekarskaya Str., 50, Lviv, 79010, Ukraine.

Tel.: +38-068-136-20-54 E-mail:bvh@ukr.net
Roman, L., Sidashova, S., Popova, I., Stepanova, N., Chornyi, V., \& Gutyj, B. (2020). Clinical symptoms of damage to the lateral surface of the tibia of dairy cows of different phenotype in the conditions of industrial dairy production. Scientific Messenger of Lviv National University of Veterinary Medicine and Biotechnologies. Series: Veterinary sciences, 22(100), 3-10. doi: $10.32718 /$ nvlvet10001

The results of the influence of the conditions of keeping Ukrainian red dairy cows on the manifestation of clinical symptoms of damage to the lateral surface of the tibia and the level of reproduction are presented. The study was conducted on the basis of an industrial dairy complex (600 dairy cows with an average productivity of $6050 \mathrm{~kg}$ of milk per lactation) as part of agricultural associations in Odessa region. The objects of the study were cows during lactation, which were kept loose in sections with rest boxes (where the floor was a special rubber mat with a thickness of $30 \mathrm{~mm}$ ). Evaluation (in points) was performed on the clinical manifestation of symptoms of damage to the skin epithelium of the lateral surface of the leg, which was injured by the rubber coating of the stall compared to the level of reproduction (service period, days/\%) and the severity of skin pigmentation of the body surface (selection melanism). Clinical, zootechnical, biometric methods were comprehensively applied to realize the purpose of research. Comparison of data $(n=462)$ visual-clinical assessment of the condition of the skin of the lateral surface of the leg, as an indicator of the adaptability of lactating cows to keep in sections with rubber flooring and the area of pigmented hair of animals of different phenotypes by coat color, showed that cows typical pigmentation, characteristic of red dairy breed (red hair occupied more than $80 \%$ of the body surface), wound lesions of the lower leg are much less common, namely: in comparison with red-spotted animals by 28.41-15.98\%, with mostly white - by 39.03-20.23\%, respectively. Due to the negative impact of open wounds of the skin of the leg on the immunity of lactating cows, it was found that increasing the number of animals with damaged epithelium as a gateway to infection, provokes an increase in the service period in cows with predominantly white or mottled color to 140.97 and 141.07 days, which is higher by 6.74 and 6.84 days, respectively, compared with red animals $(P<0.05)$.

Key words: cows, symptoms, visual-clinical assessment, lateral surface of the leg, signal parameters, color, selection melanism, adaptability, fertility, service period.

\section{Клінічні симптоми ушкодження латеральної поверхні гомілкового суглобу дійних корів різного фенотипу в умовах промислового молочного виробництва}

\author{
Л. Г. Роман ${ }^{1}$, С. О. Сідашова ${ }^{2}$, І. М. Попова ${ }^{1}$, Н. О. Степанова ${ }^{1}$, В. А. Чорнийํㅡㄹ Б. В. Гутий ${ }^{3}$ \\ ${ }^{1}$ Одеський державний аграрний університет, м. Одеса, Украӥна \\ ${ }^{2}$ Інститут розведення і генетики тварин НААН ім. М. В. Зубия, м. Київ, Украӥна
}




\section{${ }^{3}$ Львівський національний університет ветеринарної медицини та біотехнологій імені С. 3. Гюищького, м. Львів,} Україна

Надані результати впливу умов утримання корів української червоної молочної породи на прояв клінічних симптомів ушкодження латеральної поверхні гомілкового суглоба та рівень репродукиії. Дослідження проведено на базі промислового молочного комплексу (600 дійних корів із середньою продуктивністю 6252 кг молока за лактацію) у складі сільськогосподарських об'єднань Одеської області. Об'єктами дослідження були корови впродовж перебігу лактації, які безприв'язно утримувались у секиіях з боксами для відпочинку (де підлогою були спеціальні гумові килимки з товщчиною 30 мм). Оцінку (в балах) проводили за клінічним проявом симптомів ушкодження шкірного епітелію латеральної поверхні гомілки, яка травмувалась гумовим покриттям стійла, порівняно з рівнем відтворення (сервіс-період, днів; між отельний період МОП, днів; кількість тільних самиць у групі, гол./\%) та вираженістю пігментації шкірного покриву поверхні тіла (селекиійним меланізмом). Для реалізації мети дослідження комплексно були застосовані клінічні, зоотехнічні, біометричні методи. Зіставлення даних (n = 462) візуально-клінічної оцінки стану шкіри латеральної поверхні гомілки як індикатору адаптаційної здатності лактуючих корів до утримання в секціях з гумовим покриттям підлоги та площі пігментованого волосяного покриву тіла тварин різного фенотипу за забарвленням шерсті свідчили, шчо у корів з типовою пігментацією, характерною для червоної молочної породи (червона шерсть займала понад 80 \% поверхні тіла), ранові ураження гомілки трапляються значно рідще, а саме: порівняно з червоно-рябими тваринами на 28,41-15,98 \%, з переважно білими - на 39,03-20,23 \% відповідно. Зважаючи на негативний вплив відкритих ран шкіри гомілки на імунітет лактуючих корів, встановлено, щуо збільшення числа тварин з пошкодженим епітелієм як воротами інфекиії провокує ріст сервіс-періоду у корів з переважно білою або рябою мастю до 140,97 і 141,07 днів, щуо відповідно більще на 6,74 і 6,84 днів порівняно з тваринами червоної масті $(P<0,05)$.

Ключові слова: корови, симптоми, візуально-клінічна очінка, латеральна поверхня гомілки, сигнальні показники, масть, селекційний меланізм, адаптивність, заплідненість, сервіс-період.

\section{Вступ}

За останні роки досягнуто значних технологічних зрушень в організації молочного виробництва в усьому світі, прикмети чого особливо помітні в організованому секторі промислових ферм України. Наукові досягнення дозволяють в значній мірі зрозуміти механізми метаболічної адаптації корів спеціалізованих порід до інтенсивних умов експлуатації, чому сприяє впровадження на багатьох підприємствах сучасних технологій коригування чинників годівлі та інших аспектів утримання. Проте відтворення молочного стада залишається проблемною ланкою, де втрачається технологічна ефективність виробництва внаслідок невирішеності конфлікту між фізіологічними потребами організму тварин і виробничими стресами (Danylenko \& Rudyk, 2012; Mylostyvyj \& Visokos, 2016; Tancin \& Micuhova, 2018; Borshch et al., 2020; Mazur et al., 2020). Для вирішення цих питань потрібне глибше розуміння біології молочної худоби.

Вагомими факторами, що стримують розвиток великомасштабного виробництва молока в Україні, яке, за висновками ряду вітчизняних вчених, може бути прибутковим агробізнесом (Tsikhanovska, 2018), є потреба в значних інвестиціях в обладнання оптимізованих систем годівлі та утримання тварин, реконструкцію приміщень ферм тощо. Крім значної капіталоємності, ці процеси вирізняються тривалістю. Виходячи 3 названих проблем, комплектація промислових молочних підприємств поголів'ям може бути прибутковою лише за умови його високого генетичного потенціалу продуктивності та технологічно достатнього терміну господарського використання (Bashhenko et al., 2012).

Для проявлення генетичного потенціалу продуктивності тварин необхідно забезпечити відповідні умови утримання і годівлі. Особливо велике значення має узгодженість варіанта технології утримання відповідно до фізіологічних і етологічних потреб тварин. Будь-яка технологія утримання дійного стада перед- бачає різні варіювання факторів зовнішнього середовища, але всі вони мають бути спрямовані на забезпечення комфортних умов утримання 3 метою збереження здоров'я тварин і збільшення строків продуктивного використання (Shkurko, 2007; Gavrylenko, 2009; Slivinska et al., 2018; Grymak et al., 2020).

Зважаючи на те, що генотип обумовлює фенотипові особливості молочної худоби різних порід, для ефективної організації молочного виробництва потрібні обгрунтовані висновки щодо рівня адаптивності спеціалізованих і відібраних за продуктивністю корів до тривалої експлуатації у промислових умовах. Крім добору за продуктивністю, що за останні роки був домінуючим акцентом у селекції молочних стад, адаптивність $є$ вагомою характеристикою ефективності селекційного процесу. Суперечливість одержаних різними авторами результатів вивчення адаптивної здатності молочної худоби новостворених вітчизняних порід 3 високим рівнем голштинізації, свідчить про недостатню вивченість цієї проблеми, яка має безпосередній вплив на економіку галузі (Gavrylenko, 2009; Bashhenko et al., 2012; Danylenko \& Rudyk, 2012; Mylostyvyj \& Visokos, 2016). Крім того, застосовані в різних експериментах методологічні підходи до вирішення питання, суттєво відрізняються за включеними показниками і способами їх отримання, що не дозволяє коректно порівняти дані, отримані в різних умовах.

Так, білоруські науковці в результаті проведення масштабного науково-виробничого дослідження прийшли до висновку, що утримання молочних корів на монолітних гумових плитах різних виробників не викликало порушень клініко-фізіологічного стану тварин та їх захворювань (Kirikovich et al., 2012). Наші попередні дослідження показали суттєвий негативний вплив на клінічний стан кінцівок лактуючих корів за умов утримання їх в боксах з гумовим покриттям підлоги, що провокувало зниження показників надою і репродукції поголів'я (Sidashova et al., 2018). 
Питання - наскільки особливості генотипу новостворених вітчизняних порід, що перебувають наразі в процесі селекційної консолідації породи (Ilyashenko, 2012), впливають на адаптованість молочних корів до експлуатації в умовах інтенсивного виробництва, залишається недостатньо дослідженим. Наукова новизна нашого дослідження - в комплексності методологічного підходу до встановлення сигнальних показників впливу технологічних факторів (особливості умов утримання в режимі реального часу) з подальшим аналізом фізіологічних або патологічних параметрів у сигнальні періоди лактації (клінічний стан шкіри латеральної поверхні гомілки, фізіологічний період репродуктивного циклу корови) та зоотехнічних показників відтворення стада, структурованими за віком i фенотиповим проявом особливостей генотипу за мастю.

Метою дослідження було вивчення впливу на рівень репродукції умов промислової технології утримання молочних корів на гумових килимках з урахуванням адаптивної здатності у тварин з різним фенотиповим проявом селекційного меланізму. Для виконання поставленої мети були розроблені та здійснені такі завдання:

- проведено візуально-клінічну оцінку стану шкіри латеральної поверхні гомілкового суглоба лактуючих корів як показника-сигналу адаптивної здатності тварин до умов інтенсивної технології виробництва;

- проведено візуальну оцінку прояву селекційного меланізму в стаді дійних корів української червоної молочної породи з подальшим структуруванням поголів'я на три групи з різною пігментацією шерсті як фенотипового прояву особливостей генотипу: червона, червоно-ряба, переважно біла масть;

- здійснено збір і аналіз зоотехнічних показників відтворення поголів'я 3 урахуванням попереднього структурування груп за клінічними показниками стану шкіри і фенотипом за забарвленням шерсті.

\section{Матеріал і методи досліджень}

Науково-виробниче дослідження було проведено впродовж 2018-2019 господарського року на базі племрепродуктора української червоної молочної породи в умовах промислового молочного комплексу на 600 голів в Одеській області. Середньорічна продуктивність стада за 305 днів лактації становила 6252 кг молока фактичною жирністю 4,15\%. Маточне поголів'я корів на момент обстеження мало високий рівень голштинізації, наприклад, у корів 1-2 лактацій (за кількістю - це дві третини стада) умовна кровність по червоно-рябим голштинам складала: ЧС (червона степова) 12,5 \% + Г (голштинська) 87,5 \%. Впродовж 15 років в господарстві велась цілеспрямована селекційна робота 3 підвищення продуктивності власного поголів'я червоної степової породи південного жир- номолочного типу шляхом штучного осіменіння корів і телиць імпортованою спермопродукцією голштинських червоно-рябих плідників-поліпшувачів (виробництва провідних селекційних центрів США і Канади) (Sidashova et al., 2018; 2020).

На базі племрепродуктора було проведено кардинальну реконструкцію приміщень, тому зоогігієнічні умови утримання дійного поголів'я загалом відповідали сучасним технологічним нормативам промислового потокового виробництва молока: безприв'язне утримання у великих секціях приміщень легкого типу 3 плановим переміщенням тварин відповідно до лактаційного періоду. Покриття підлоги в стійлах-боксах для відпочинку корів було у вигляді гумових килимків (без підстилки) зарубіжного виробництва (товщина 30 мм), зі строком попередньої експлуатації 11,5 року (рис. 1). Встановлене відповідно до вимог виробників це гумове покриття у високих боксах відрізнялось понадміцним профілем "повітряна подушка” із зонами різної м'якості, що повинні були забезпечувати максимальний і тривалий комфорт у стійлі для відпочинку корів. Вся продукція виробника гумових покриттів була сертифікована відповідно до світової норми ISO 9001 та перевірена на якість в умовах власних лабораторій.

Раціони годівлі (повнозмішаний монокорм) відповідали зоотехнічним вимогам за основними показниками поживності, все поголів'я було забезпечено плановими протиепізоотологічними i санітарними заходами та вакцинаціями проти інфекційних хвороб. В транзитний період корови перебували під наглядом ветеринарної служби за планом гінекологічної диспансеризації.

Візуально-клінічну методику оцінки стану латеральної поверхні гомілки і аналізу рівня селекційного меланізму стада нами було детально викладено в попередніх публікаціях (Sidashova et al., 2018); за основу порівняння взято оцінку комфортності місць для лежання за системою Дж. Ноцека з модифікацією відповідно до дослідних цілей (Shkurko, 2007) та методику українських вчених із визначення селекційного меланізму великої рогатої худоби (Konovalov \& Starodub, 2019). Відповідно до застосованої робочої шкали оцінювали: потертості шерсті латеральної поверхні гомілки без ушкодження епітелію шкіри - 12 бали; візуально виявлені лисі місця і відкриті ранові поверхні шкіри (ворота інфекції) загальною площею 1-3 см ${ }^{2}-3$ бали; пошкодження шкіри площею більше ніж $3 \mathrm{~cm}^{2}$ та/або клінічно проявлені симптоми ураження суглоба (набряк, запалення, свищ, ін.) 3 візуально встановленими локомоторними дефектами різної важкості - 4-5 балів (рис. 1).

На фото (рис. 2) показані різні варіанти пігментації шерсті поверхні тіла корів, що характеризують три різні фенотипові групи: червона масть, червоно-ряба i переважно біла. 


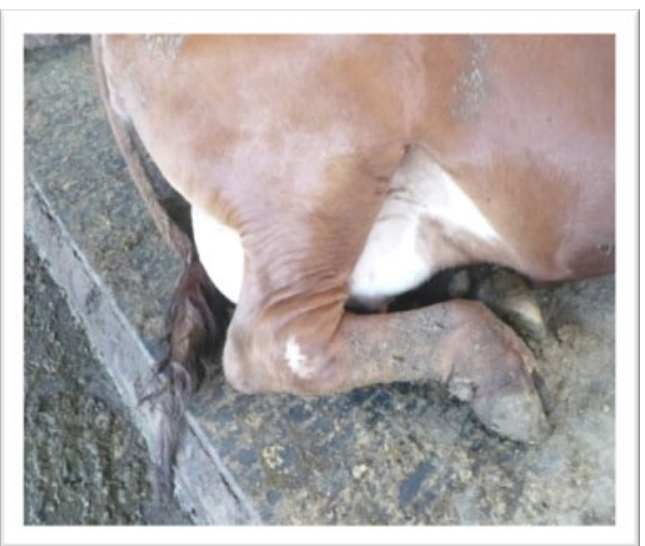

Рис. 1. Гумове покриття у стійлі для відпочинку корови та типові пошкодження латеральної поверхні гомілкового суглоба (візуально-клінічна оцінка - 3 бали), що виникають під час контакту з гумою

Показники репродукції (сервіс-період, днів; МОП, днів; кількість тільних корів, гол./\%) були отримані 3 комп'ютерної бази даних господарства (“DairyPlan”). Підсумовані результати обчислені методами математичної статистики засобами програмного пакету IBM Statistics - 2011 (Version 20).

\section{Результати та їх обговорення}

Як показав моніторинг візуальної оцінки латеральної поверхні гомілкового суглобу (табл. 1), клінічний стан шкіри корів суттєво погіршувався 3 ростом терміну лактації. Якщо в транзитний період (до 45 лактаційних днів) лише у 28,95 \% корів виявляли відкриті рани латеральної поверхні гомілки, то у тварин на піку лактації (45-120 днів) такий стан спостерігався вже у 59,58 \%, а $з$ початку другої половини лактації - у 85,41 \%. Привертає увагу та обставина, що значні пошкодження не тільки латеральної поверхні гомілки, а й усього морфологічнофункціонального відділу гомілкового суглоба зростає

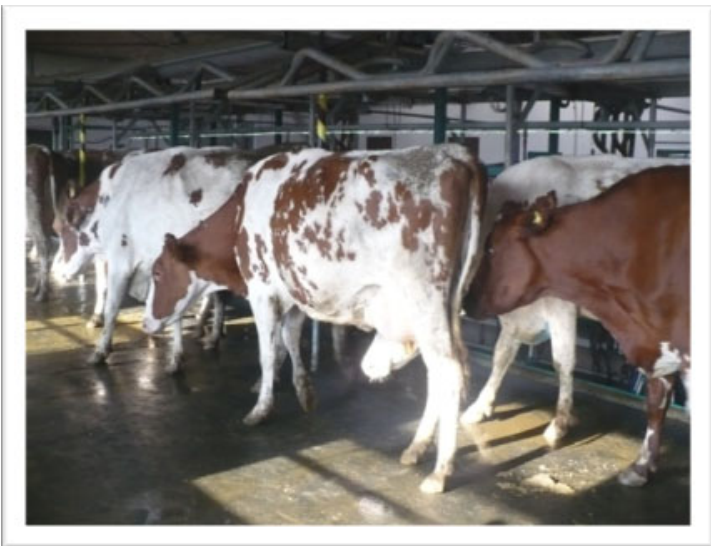

Рис. 2. Характерний прояв різного рівня селекційного меланізму корів української червоної молочної породи: у передньої тварини переважно біла масть, у середньої - червоно-ряба, остання тварина $з$ типовою червоною мастю за незначних білих плям

в міру збільшення лактаційного терміну. Відкриті садна гомілки з візуально встановленими симптомами патології суглоба і відповідно проявленими при спостереженні за ходою корови локомоторними дефектами зафіксовано в 39,25 \% після 305 днів лактації, тимчасом як відразу після надходження тварин 3 пологового відділення такі патології візуально відсутні (в приміщеннях для нелактуючих корів не застосовувалась гумова підлога). Якщо кореляційні зв'язки між показниками незначного пошкодження латеральної поверхні гомілки у дійних корів виявлені лише в тенденції (Р > 0,05), що свідчило про наявність різноспрямованих векторів біологічного та/або господарчого впливу на стан здоров'я тварин, то кореляція між показниками клінічного ураження шкіри від 3-х до 4 i 5 балів була вірогідна і суттєва (Р $<0,01)$, чим висвічувалась закономірність поглиблення патологічних станів кінцівок впродовж терміну збільшення контакту латеральної поверхні гомілки корів з гумою підлоги.

\section{Таблиця 1}

Клінічний профіль стану латеральної поверхні гомілки лактуючих корів за перебігу лактації

\begin{tabular}{|c|c|c|c|c|c|}
\hline \multirow{2}{*}{ Показники* } & \multicolumn{5}{|c|}{ Лактаційний період, днів } \\
\hline & $\leq 45$ & $46-120$ & $121-305$ & $\geq 305$ & Разом $(\mathrm{M} \pm \mathrm{m})$ \\
\hline Всього обстежено корів, гол./100 \% & 76 & 94 & 185 & 107 & 462 \\
\hline \multicolumn{6}{|c|}{ Візуально-клінічний стан латеральної поверхні гомілкового суглобу: } \\
\hline 2 бали, гол. & 54 & 38 & 27 & 17 & 136 \\
\hline$\%$ & 71,05 & 40,43 & 14,59 & 15,89 & $29,44 \pm 26,52$ \\
\hline 3 бали, гол. & 22 & 33 & 87 & 48 & 190 \\
\hline$\%$ & 28,95 & 35,11 & 47,03 & 44,86 & $41,13 \pm 8,46^{\mathrm{a}}$ \\
\hline 4-5 балів, гол. & 0 & 23 & 71 & 42 & 136 \\
\hline$\%$ & 0,00 & 24,47 & 38,38 & 39,25 & $29,44 \pm 18,31^{\mathrm{b}}$ \\
\hline
\end{tabular}

Примітка: *-методика оичінк надана в тексті; $a-b(P<0,01), r=+0,956$

Проникнення через пошкоджений епітелій шкіри патогенних бактерій із довкілля в організм корів становить потенційну загрозу не тільки для їхнього здоров'я. Якщо концентрація патогенів недостатня для клінічного прояву симптомів захворювання, то обов'язковими є втрати енергії і поживних речовин на їх нейтралізацію організмом тварини, що погіршує економіку утримання стада. Це стається тому, що відповідна реакція імунної системи потребує більше енергії і організм тварини бореться 3 бактеріями за 
поживні речовини. Інфікування організму через запалені мацеровані ділянки шкіри на поверхні гомілки створює умови для хронізації запальних латентних процесів не тільки в епітелії шкіри і тканинах суглоба, а й унаслідок проникнення (інтралокації) бактерій в інші органи тварин, а також спричиняє зрушення балансу мікрофлори на слизових оболонках різних порожнин тіла, в тому числі слизових репродуктивної системи. Внаслідок цього формуються умови для дисбактеріозу слизових статевих шляхів, що негативно впливає як на прояв статевої активності, так і на рівень переживаності гамет і приживленості ембріонів на поверхні пошкодженого ендометрію. Руйнування цілісності епітелію шкіри, а також пошкодження мікрофлори слизових стає пусковим механізмом розвитку поліморбідного стану у високопродуктивних корів, що негативно відбивається на репродуктивному здоров ї та рівні молоковіддачі (Rublenko \& Vlasenko, 2011).

Крім того, варто звернути увагу на хронічну інтоксикацію організму лактуючих корів ендогенними бактерійними токсинами, що суттєво поглиблює стан імуносупресії на фоні навіть незначних кількостей мікотоксинів, що поступають 3 довкілля та 3 кормами i разом створюють негативний синергічний вплив на життєдіяльність і продуктивність тварин. За даними досліджень останніх років щодо вивчення механізмів асоційованого токсичного впливу полімікотоксикозів спільно з умовно патогенною мікрофлорою на різні види ссавців, доведено наявність такої дії практично в кожному господарстві, навіть при добре налагодженому менеджменті стада.

Застосування потокової системи переміщення тварин із секції до секції (з однієї групи до іншої залежно від терміну тривалості лактації і рівня продукування молока) є невід'ємним стрес-фактором інтенсивної технології молочного виробництва. Тому дійне поголів'я постійно перебуває під тиском техногенних стресів і коливань видової асоціації мікрофлори слизових, що зумовлює перенавантаження імунної системи корів, яка і без того працює дуже напружено внаслідок генетично обумовленої здатності до високої молокопродукції.

Зіставлення даних чисельності тільних в групах корів другої половини лактації, що мали різний клінічний стан латеральної поверхні гомілки (рис. 3), свідчило про сталу тенденцію до зниження кількості запліднених самиць в групах 3 клінічно вираженою симптоматикою пошкоджень.

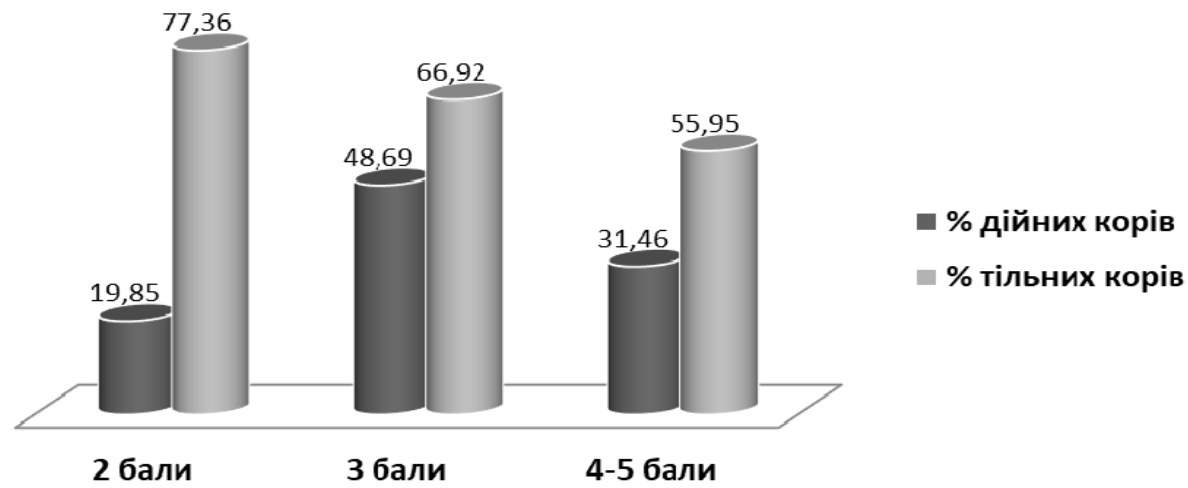

Рис. 3. Динаміка співвідношення чисельності в стаді корів другої половини лактації з різними клінічними симптомами пошкодження шкіри латеральної поверхні гомілки та рівня встановленої тільності $(\mathrm{n}=267)$

Якщо в групі корів, які не мали відкритих ран гомілки, після 305 днів лактації тільними були 77,36 \%, то у тих, що мали пошкоджений епітелій шкіри площею не більше ніж $3 \mathrm{~cm}^{2}$ - вже 66,36 \%, а зі значними патологічними проявами в ділянці гомілкового суглоба рівень заплідненості опускався до 55,95 \%. Відповідно в таких корів тривалість міжотельного періоду суттєво збільшувалась, поширеність симптоматичного хронічного безпліддя провокувала високий рівень вибракування, незважаючи на вірогідно високий продуктивний потенціал (Sidashova, 2019).

Встановлений зв'язок між клінічними показниками пошкодження шкіри внаслідок травмування гумовою поверхнею підлоги свідчив про підвищення агресивності технології утримання дійних корів без підстилки. Властивості зовнішніх покровів великої рогатої худоби до збереження цілісності шкіри за постійного травмування гумою підлоги обмежені біологічно, бо еволюційно анатомо-функціональна структура гомілкового суглобу набула наявної будови, придат- ної для постійного руху тварин в природному середовищі або на пасовищі, під час тривалого попереднього селекційного відбору. За сучасними вимогами, корови молочних комерційних порід повинні спочивати лежачи не менше 10,5-11,5 години на добу, що стимулює продукування у вимені відповідної кількості молока. Досить часто корови мають потребу підніматися з гумової поверхні підлоги: для виходу до доїльної зали, до годівниці, напувалки тощо. У процесі контакту латеральної поверхні гомілкового суглобу 3 гумою спостерігається постійне травмування цього суглоба, бо він еволюційно не пристосований для частого стикання 3 твердою штучною поверхнею (у великої рогатої худоби в нормі не розвивається синовіальна сумка гомілкового суглоба) (Kalynovskyj et al., 2010). За високого імунітету та цілісності шерстного покриву кінцівок у корів може поступово формуватись захисна слизова бурса в ділянці гомілкового суглоба, але у випадку постійної травми і низької резистентності тварини захисна бурса не встигає сфо- 
рмуватись і після облисіння шкіри виникає садно, потім склероз шкіри 3 подальшою широкою зоною гнійного розпаду тканин i хронічного запалення 3 больовим синдромом та розвитком локомоторних дефектів.

Таким чином, можна спостерігати негативний вплив особливостей технології утримання на стан шкіри кінцівок корів, який є одночасно сигнальним показником імунного статусу тварин, що детермінує регенераційні здатності епітелію шкіри, та адаптивності тварин до утримання у промислових комплексах.

Серед підконтрольного племінного стада української червоної молочної породи спостерігались різні фенотипові варіанти за пігментацією шерсті - від типової червоної масті, яка була попередньо домінуючою у материнському стаді червоної степової породи, до переважно білого забарвлення шерсті, що $\epsilon$ характерним для плідників-поліпшувачів червонорябої голштинської породи зарубіжної селекції. Структура стада, що склалася внаслідок тривалого періоду голштинізації місцевої популяції червоної худоби південного типу, за селекційним меланізмом подана нами в попередніх публікаціях (Sidashova, 2018; 2019), інтерпретація отриманих даних дає спірні висновки і потребує подальшого накопичення даних. На рисунку 4 показано динаміку впливу рівня селекційного меланізму на прояв клінічних симптомів ушкодження шкіри гомілки у корів впродовж лактації.

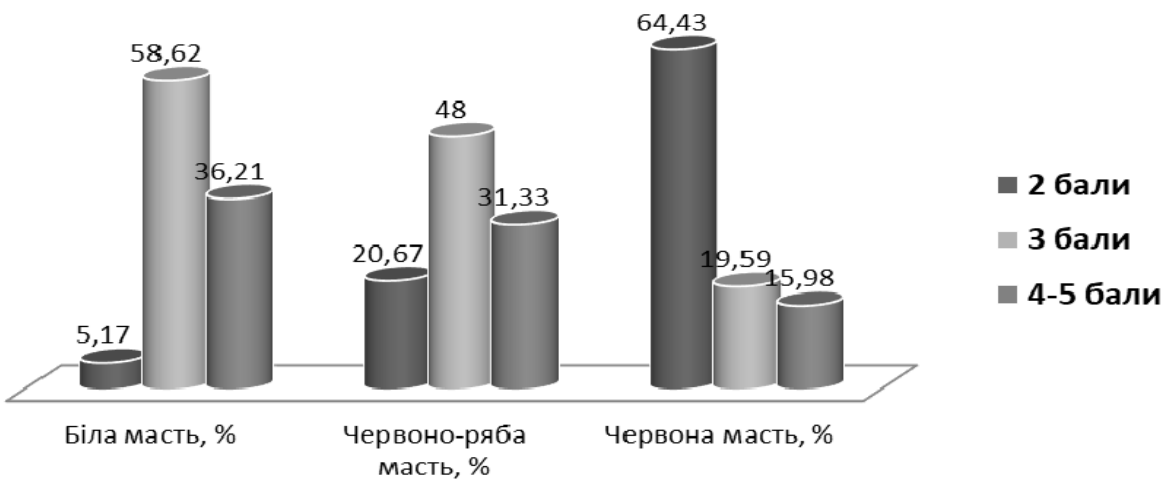

Рис. 4. Поширеність клінічних ушкоджень шкіри латеральної поверхні гомілки у лактуючих корів із різним рівнем пігментації поверхні тіла $(\mathrm{n}=402)$

Корови 3 характерною червоною пігментацією більшості поверхні тіла мали найменший рівень відкритих ран гомілки, в тому числі 3 клінікою уражень суглоба - лише 15,98 \%. Найбільше відкритих ранових ушкоджень епітелію шкіри гомілки виявляли у тварин 3 переважно білою шерстю $(58,62 \%)$, зокрема симптоми глибоких ушкоджень були у $36,21 \%$. У корів червоно-рябої масті клінічні показники - сигнали зниження резистентності організму і погіршення регенераційної здатності шкіри були близькі до тварин з білою шерстю, відповідно 48,00 і 31,33 \%.

Аналіз показав, що червона масть фенотипово характеризує генотип тварин 3 більшою адаптивністю до агресивної дії утримання в умовах промислового комплексу з постійним контактом гомілкового суглоба $з$ гумовою підлогою.

Порівняння тривалості сервіс-періоду повновікових корів із різним фенотипом за мастю достовірно підтвердив встановлену тенденцію (табл. 2).

\section{Таблиця 2}

Ефективність відтворення повновікових молочних корів різного фенотипу за селекційним меланізмом $(\mathrm{n}=188)$

\begin{tabular}{|c|c|c|c|c|c|c|}
\hline \multirow{3}{*}{ Групи корів за віком } & \multicolumn{6}{|c|}{$\begin{array}{l}\text { Тривалість сервіс-періоду за різного прояву селекційного меланізму } \\
(\mathrm{M} \pm \mathrm{m}), \text { днів } \\
\end{array}$} \\
\hline & \multicolumn{2}{|c|}{ Червона масть } & \multicolumn{2}{|c|}{ Червоно-ряба масть } & \multicolumn{2}{|c|}{ Переважно біла масть } \\
\hline & Гол. & Сервіс-період & Гол. & Сервіс-період & Гол. & Сервіс-період \\
\hline 2 лактація & 33 & 128,79 & 58 & 106,69 & 17 & 114,18 \\
\hline 3 лактація & 21 & 146,19 & 30 & 191,33 & 11 & 175,45 \\
\hline 4 лактація & 8 & 125,25 & 6 & 218,50 & 4 & 160,00 \\
\hline Разом обстежено & 62 & $134,23 \pm 11,21^{\mathrm{a}}$ & 94 & $141,07 \pm 58,31^{\mathrm{b}}$ & 32 & $140,97 \pm 31,86$ \\
\hline
\end{tabular}

Примітка: $a-b(P<0,05), r=0,129$

Корови 3 переважно червоною мастю показали ефективніше запліднення (сервіс-період 134,23 дня) порівняно 3 червоно-рябими (сервіс-період 141,07 дня) і білими (сервіс-період 140,97 дня). Одночасно треба зауважити, що міжотельний період в усіх обстежених групах був суттєво вищим за рекомендований для рентабельного молочного виробництва рівня (від 419 до 426 днів). За даними українських вчених, важливою складовою адаптивності тварин до умов зовнішнього середовища $\epsilon$, крім рівня молочної продуктивності, і тривалість міжотельного періоду, протяглість якого детермінована сервіс-періодом. Співвідношення цих показників лімітує інтенсивність використання корів. Так, збільшення міжотельного 
періоду понад 365 днів веде до зменшення надоїв в розрахунку на 1 день життя і за весь період експлуатації, що негативно впливає на рентабельність виробництва (Gavrylenko, 2009; Danylenko \& Rudyk, 2012; Mylostyvyj \& Visokos, 2016).

Проведене дослідження надало для розгляду дані, які дозволили в режимі реального часу без застосування дорогого обладнання та коштів оцінити зв'язок стану здоров'я дійного стада, його відтворювальної здатності та адаптивності до штучного середовища.

Одним із важливих факторів, що впливає на адаптивну здатність тварин, $є$ іiі генетична зумовленість, тому виявлена властивість корів $з$ типовою червоною пігментацією шерсті поверхні тіла до кращої регенерації шкіри показує перспективний напрямок селекції та ефективнішого ветеринарного супроводу поголів'я. Вірогідно, виходячи із даних вітчизняних науковців, червона масть $є$ маніфестацією консолідованості генотипу тварини, тобто до певної міри бажаною селекційною ознакою (Ilyashenko, 2012). Проблему консолідації новостворених українських молочних порід було висвітлено в наукових розробках українських вчених Ф. Ф. Ейснера, Ю. П. Полупана, М. І. Бащенка та інших (Polupan \& Koval, 2003; Bashhenko et al., 2012). Консолідовані тварини мають найменший розмах мінливості гамет за спадковими факторами селекційних ознак і тому дають більш вирівняний за типом i продуктивністю молодняк. Неконсолідовані тварини дають найбільший розмах мінливості гамет за спадковими факторами селекційних ознак і створюють високу фенотипну мінливість у нащадків.

Таким чином, економічно доцільним є розведення і селекція у племінних господарствах промислового типу вітчизняних порід молочної худоби із генетичною стійкістю до захворювань і агресивного впливу інтенсивних технологій утримання i експлуатації, добір яких можливо проводити за врахування рівня пігментації зовнішніх покровів тіла тварин.

\section{Висновки}

1. Візуально-клінічна оцінка стану латеральної поверхні гомілки дійних корів, що утримувались на гумових килимках без підстилки, виявила сталу тенденцію зростання кількості тварин із клінічними симптомами пошкодження шкіри та інших тканин гомілкового суглобу впродовж перебігу терміну лактації, а саме: за відсутності таких пошкоджень на початку роздою, після 305 днів лактації їх зафіксовано у 70,17 \% корів.

2. Встановлено, що за збільшення прояву симптомів ушкодження латеральної поверхні гомілки знижується рівень заплідненості корів у другій половині лактації, а саме: серед самиць, які не мали клініки відкритих ран шкіри гомілки, було 77,36 \% тільних, а серед тварин з помітними пошкодженнями і локомоторними дефектами тільних було від 66,92 \% до 55,95 \% залежно від важкості патологічного стану кінцівок.

3. Достовірно встановлено позитивний вплив високого рівня пігментації волосяного покриву тіла корів (червона масть) на вищу стійкість шкіри до пошкоджень латеральної поверхні гомілки (відкриті рани виявлено в 35,57 \%). У корів 3 переважно білою шерстю i червоно-рябої масті патологічний стан гомілки спостерігався значно частіше, відповідно у 94,83 і 79,33 \% випадків $(\mathrm{P}<0,05)$.

\section{References}

Bashhenko, M. I., Ruban, Yu. S., \& Biryukova, O. D. (2012). Obgruntuvannya napryamiv rozvytku chervono-ryabyx porid v Ukrayini. Rozvedennya i genetyka tvaryn, 46, 16-18 (in Ukrainian).

Borshch, O. O., Gutyj, B. V., Sobolev, O. I., Borshch, O. V., Ruban, S. Yu., Bilkevich, V. V., Dutka, V. R., Chernenko, O. M., Zhelavskyi, M. M., \& Nahirniak, T. (2020). Adaptation strategy of different cow genotypes to the voluntary milking system. Ukrainian Journal of Ecology, 10(1), 145-150. doi: 10.15421/2020_23.

Danylenko, V. P., \& Rudyk, I. A. (2012). Do py`tannya efektyvnosti vykorystannya molochnyx porid u gospodarstvi. Rozvedennya i genetyka tvaryn, 46, 63-65 (in Ukrainian).

Gavrylenko, M. S. (2009). Vplyv genotypovyx i paratypovyx faktoriv na formuvannya molochnoyi produkty`vnosti koriv ukrayins 'koyi chervonoyi molochnoyi porody`. Rozvedennya i genetyka tvaryn, 43, 78-84 (in Ukrainian).

Grymak, Y., Skoromna, O., Stadnytska, O., Sobolev, O., Gutyj, B., Shalovylo, S., Hachak, Y., Grabovska, O., Bushueva, I., Denys, G., Hudyma, V., Pakholkiv, N., Jarochovich, I., Nahirniak, T., Pavliv, O., Farionik, T., \& Bratyuk, V. (2020). Influence of "Thireomagnile" and "Thyrioton" preparations on the antioxidant status of pregnant cows. Ukrainian Journal of Ecology, 10(1), 122-126. doi: 10.15421/2020_19.

Ilyashenko, G. D. (2012). Konsolidaciya za osnovnymy gospodarsky korysnymy oznakamy` u stadax ukrayins`ky`x chervonoyi i chervono-ryaboyi molochnyx porid. Rozvedennya i genetyka tvaryn, 46, 126-129 (in Ukrainian).

Kalynovskyj, G. M., Kovalchuk, Yu. V., Kovalov, P. V., Karlyuk, V. V., Zaxarin, V. V., Afanasyeva, L. P., Gryshhuk, G. P., \& Omelyanenko, M. M. (2010). Travmy lateralnoyi poverxni zaplesnevogo sugloba i yix uskladnennya u koriv. Veterynarna medycyna Ukrayiny, 8, 1-21 (in Ukrainian).

Kirikovich, S. A., Puchka, M. P., Moskalev, A. A., Kovalevskij, I. A., Tatarinova, G. M., Shmatko, N. N., Balueva, N. A., \& Nagornaja, Z. M. (2012). Izuchenie vlijanija rezinovyh napol'nyh pokrytij na fiziologicheskoe sostojanie korov. Rozvedennja i genetika tvarin, 46, 296-299. URL: http://nbuv.gov.ua/UJRN/rgt_2012_46_118 (in Russian).

Konovalov, V. S., \& Starodub, L. F. (2019). Mutaciya "red" yak provokator spontannogo mutagenezu chervono-ryaboyi velykoyi rogatoyi xudoby. Rozvedennya i genetyka tvaryn, 43, 173-180 (in Ukrainian).

Mazur, N. P., Fedorovych, V. V., Fedorovych, E. I., Fedorovych, O. V., Bodnar, P. V., Gutyj, B. V., Kuziv, M. I., Kuziv, N. M., Orikhivskyi, T. V., Grabovska, O. 
S., Denys, H. H., Stakhiv, N. P., Hudyma, V. Yu., \& Pakholkiv, N. I. (2020). Effect of morphological and biochemical blood composition on milk yield in Simmental breed cows of different production types. Ukrainian Journal of Ecology, 10(2), 61-67. doi: $10.15421 / 2020110$.

Mylostyvyj, R., \& Visokos, M. (2016). Ekologogenetychne obg'runtuvannya adaptacijnoyi zdatnosti golshty`ns`koyi xudoby` yevropejs`koyi selekciyi v umovax Prydniprovya. Theoretical and Applied Veterinary Medicine, 4(1), 140-143. URL: https://bulletinbiosafety.com/index.php/journal/article/view/115 (in Ukrainian).

Polupan, Yu. P., \& Koval, T. P. (2003). Stvorennya ta perspektyvy selekciyi ukrayinskoyi chervonoyi molochnoyi xudoby (na prykladi plemzavodu "Zorya"). Rozvedennya i genetyka tvaryn, 36, 12-15 (in Ukrainian).

Rublenko, M. V., \& Vlasenko, S. A. (2011). Problemy zabezpechennya zdorovya vysokoproduktyvnyx koriv. Veterynarna medycyna: mizh vid. temat. nauk. zb. 95, 397-400 (in Ukrainian).

Shkurko, T. P. (2007). Rekomendaciyi po pidvyshhennyu tryvalosti produktyvnogo vykorystannya molochnoyi xudoby. Dnipropetrovs`k, In-t tvarynnycztva centralnyx rajoniv (in Ukrainian).

Sidashova, S. O (2018). Dynamika selekcijnogo melanizmu stada ukrayinskoyi chervonoyi molochnoyi porody i produktyvno-reproduktyvni pokaznyky dijnyx koriv. Naukovo-inf. visnyk XDAU, 11, 57-63 (in Ukrainian).

Sidashova, S. O. (2019). Selekcijnyj melanizm i adaptacijni zdatnosti koriv $\mathrm{V}$ umovax promyslovyx texnologij utrymannya. Mat. naukovo-prakty`chnoyi konferenciyi prof.-vykladaczkogo skladu zootexnichnogo fakultetu ODAU "Aktualni problemy tvarynnycztva" 4.04.2019 r. [Elektronny”j resurs]. URL: http://osau.edu.ua/uk/kontakti (in Ukrainian).

Sidashova, S. O., Kovtun, S. I., \& Scherbak, O. V. (2018). Ethological and morpho-functional features of sexual cyclicity at cows in conditions of industrial production of milk. Visnyk agrarnoyi nauky, 7, 42-47 (in Ukrainian).

Sidashova, S., Gutyj, B., Khalak, V., \& Humeny, O. (2020). Influence of complex action of probiotic and specific prophylaxis of associated mucosal diseases on some quantitative traits of dairy cattle performance. Scientific Messenger of LNU of Veterinary Medicine and Biotechnologies. Series: Veterinary Sciences, 22(97), 79-87. doi: 10.32718/nvlvet9714.

Slivinska, L., Fedorovych, V., Gutyj, B., Lychuk, M., Shcherbatyy, A., Gudyma, T., Chernushkin, B., \& Fedorovych, N. (2018). The occurrence of osteodystro-phy in cows with chronic micronutrients deficiency. Ukrainian Journal of Ecology, 8(2), 24-32. doi: $10.15421 / 2018305$.

Tancin, V., \& Micuhova, L. (2018). Possible physiological and environmental affecting milk production of health of dairy cows: A. Review. Slovak J. Anim. Sci., 51(1), 3240. URL: http://www.cvzv.sk/slju/18_1/5 tancin.pdf.

Tsikhanovska, V. M. (2016). Stan ta perspektyvy rozvytku rynku moloka ta molochnykh produktiv Ukrainy. Ekonomika. Upravlinnia. Innovatsii. Seriia: Ekonomichni nauky, 1. URL: http://nbuv.gov.ua/ UJRN/eui_2016_1_24 (in Ukrainian). 